\title{
Towards a Social-Relational Dialectic for World Politics
}

\author{
By Shannon Brincat ${ }^{1}$
}

Abstract:

Dialectics remains an under-utilised methodology in contemporary IR theory which represents a significant limitation to the study of world politics, particularly regarding processes of transformation and change within it - an oversight that this paper intends to redress. This article has two primary goals. Firstly, it aims to reconstruct and build upon the small but robust debate concerning the validity of dialectics in IR that has been championed previously by Alker and Biersteker, and Heine and Teschke respectively. Secondly, it contrasts dialectical and deterministic approaches to IR, as exemplified in Coxian Critical Theory and neo-realism respectively, as a means to showcase the merits of the former as an approach to the study of social change in world politics. The ultimate aim of the paper is to offer the groundwork of a socialrelational dialectical approach to world politics that is focused on the intersubjective engagements between human-beings which can be developed in future research. Through such an analytic, the dialectical processes in social life are shown to be open-ended and the paper rejects any understanding of 'inevitable' progress/regress or teleological endpoint. On the one hand, this account of dialectics promises greater analytical potential for understanding processes of change in world politics but on the other, indicates the potential for the irrational toleration of contradiction and antagonism as an accepted feature of social life. Ultimately, the paper argues that the skilled dialectician should emphasise human agency and intersubjectivity within a social-relation dialectical approach to world politics.

\section{Biography:}

Shannon Brincat is a Ph.D Candidate in the School of Political Science and international Studies at the University of Queensland, Brisbane. His thesis research focuses on the concept of emancipation in Critical International Relations Theory (CIRT) and he has wider research interests in the concepts of utopianism, anarchism, Marxism and dialectics in world politics. Shannon has publications in the Review of International Studies, Constellations, the Australian Journal of Legal Philosophy and the Journal of International Political Theory amongst others. He is also an editor for the journal GlobalDiscourse.

\author{
Contact details: \\ shannonbrincat@yahoo.com.au or s.brincat@uq.edu.au
}

\author{
Mr. Shannon Brincat (BA (Hons) LLB (Hons), Phd Candidate) \\ Global Discourse, Editor, Australasian Region (http://global-discourse.com) \\ School of Political Science and International Studies | The University of Queensland | \\ Brisbane Qld 4072 | Australia |
}

Keywords:

Dialectics, social-relations, change, structure/agency, determinism/open-endedness 


\section{Towards a Social-Relational Dialectic for World Politics}

\section{Introduction}

Dialectics offers nothing less than a means to reframe the social ontology of world politics, from one of alleged stasis and immutability, to one of process, change, and the social-relations that generate them. This may seem a grandiose claim, yet, by reframing the social ontology of IR, I do not mean to replace Hobbesian nominalism or neo-realism's systemic reproduction thesis with another closed ontos but to advocate an entirely different approach that focuses on change in world politics through the generative mechanisms within social-relations. It is not an ontology of states or political subjects but of social-relations themselves, the engagements between persons, as simple or as complex as they may be, in which states and political subjects are seen as parts of the social whole. This should not be mistaken as an unnecessarily complex expression of 'interactionism' as causality in social life, an assertion which risks confusing dialectics as a garbled metaphor of dynamic interdependence (Mefford in Alker, 1982: 31). Rather, a social-relational dialectic helps reveal the immanent tendencies within global or transnational political community ${ }^{2}$ that have remained under-theorised in dominant approaches to world politics, preoccupied as they are with state relations rather than human relations. So while we may well disagree with the metaphysical suppositions of Hegel's objective-idealist dialectic and view with suspicion the teleological assumptions of some crude forms of dialectical materialism ('Diamat'), ${ }^{3}$ nevertheless dialectics can, if properly interpreted, offer fruitful areas for research in world politics. This paper aims to provide only a basic groundwork of such a dialectical approach to the study of world politics, a full account of which would otherwise necessitate voluminous treatment. Some may call this a dialectical methodology, which I am not opposed to, so long as by the term 'methodology' one does not mean a rigid set of principles or ready-made formulae that are to be forcefully applied to any question - dialectics is nothing if not a "live" method that enables us to look critically at human reality and the potential futures therein (Marković, 1965: 80).

So where does contemporary IR theory stand as regards the dialectic (Marx, 1967: 315)? There has been a widespread suspicion held against dialectics, ideological baggage derived from Cold War misconceptions, that has resulted in its neglect by traditional approaches to IR. Such mystifications however should no longer unnecessarily obfuscate what could potentially offer great insight into world politics, as dialectics is an approach that seems especially well suited to the fundamentally interactive character of IR's subject matter. ${ }^{4}$ My aim is to reinvigorate dialectics in the so-called intersubjective turn in IR theory - a period which, ostensibly, should make the discipline more receptive to a method that focuses on social-relations - by outlining a dialectical method that builds on the work of Heine and Teschke (1996, 1997, 2002) and Alker and Biersteker (1984). It does not purport to provide a concrete application or case study of the method, something that may be taken up in later research. Yet it does view the rehabilitation of dialectics as 
an important task that may yield impressive results in the study of IR, particularly regarding our ability to understand the processes of social change within world politics. As world politics involves a complex array of networks, social systems and a myriad of social phenomena (at local, regional and interstate levels), a social-relational dialectical approach deserves serious consideration as a potential framework to help understand change within these dynamic multi-level social conditions. What renders social-relational dialectics such a capable method for understanding processes is how it focuses on particular phenomena within the totality of social-relations rather than their isolation or abstraction (Jay, 1996: 54, 79), the contextual analysis of these the interconnectedness between such phenomena, and the immanent tendencies for social transformation that this engenders (Sciabarra, 2002: 393). In this way, dialectics contributes to understanding what Suganami has called the "causal narrative" in world politics and history (Suganami, 2008: 328). It views social change as reliant on human agency (situated within the totality of surrounding conditions and circumstances) rather than self-perpetuating systemic forces, and understands change as ontologically open-ended or 'possibilistic', rather than determined or teleological (Brincat, 2009a).

This article outlines the essential features of a social-relational dialectic by emphasising the intersubjective basis of the processes of change in world politics embedded in the manifold network of global social relations. Its central claim is that a dialectical methodology of world politics is, and must be, thoroughly intersubjectivist as it is through human interaction that contradiction and social antagonism are generated, wherein lies the dialectical catalyst of social transformation. The dialectics of world politics, in this view, is inherently social - it is the encounter of intersubjectivities, the engagement with the 'Other'. The first task of this paper is therefore to reconstruct the major debates concerning dialectics in the discipline of IR theory and the second to illustrate the benefits of dialectical analysis over traditional approaches to world politics. Unfortunately however, the substantive task of exploring an example of such a socialrelational dialectic in the form of recognition processes in world politics must await future research.

\section{A reconstruction of dialectics in IR theory}

The dialectical tradition is characterised by its ontological focus on change through contradiction, an approach that views "unifying social contradictions and necessarily opposed developments as the essential bases of human existence" (Alker, 1981: 70). Stated simply, dialectics holds that change results from the internal dynamism of society, from the interactions between human-beings that leads, inevitably, to intersocietal tension and the potential sublation of these contradictions to different though not necessarily 'higher' - forms. Dialectics has moved through five conceptual stages in its philosophical development (Thalheimer, 1927: Chapter 10) ${ }^{5}$ with common emphasis today being placed on the concept as a method (epistemological dialectics), a set of laws or principles governing a sector or whole of reality (ontological dialectics), and as the movement of history (relational dialectics) (Bottomore et al, 1985: 122). These represent different but complementary aspects of dialectics and should not be seen as being mutually exclusive. In this paper, dialectics is understood in an expansive sense as 
referring to ways in which we can understand the world (epistemology), as an assumption of the interconnected, contradictory, and dynamic nature of the world (ontology), and as a way to explore social change in the world (methodology). It is through this three tiered approach that dialectics offers a robust method for the study of change within world politics because its epistemology and ontology are fundamentally related; what we can understand about the world stems from the interconnections, contradictions and dynamism within it. The promise of dialectics is that it offers an insight into the question of the social processes of change but without - as we shall see - falling to determinism, teleology or theoretical monism.

Yet there are considerable dangers if one adopts uncritically the central tenets of dialectics; it may lead to alleged deterministic or predictive accounts of change as has been so pronounced in Soviet 'Diamat' literature, or it may assume a mechanistic dialectical 'triad' (thesis, antithesis and synthesis) that supposes the third stage ('synthesis') automatically results in overcoming contradiction, rather than its sublation. Dialectics is not a theory that, as Popper and Mayo have so erroneously suggested, posits that "something" develops mechanistically (2002: 419-451, 1960: 31). Even Hegel condemned the dialectical triad as a "lifeless schema", inappropriate for the study of social-relations which are, at all times, complex and multi-faceted (Mueller, 1958: 411414; Hegel, n.d: 'Preface'). Rather than an inevitable, progressive movement to the Absolute, in Hegel we see a history permeated with "unintended results, and the irony of sudden reversals" and as such the "fateful myth" that dialectics is reducible to a rigorous method that permits 'predictions' simply deserves no quarter (Kaufmann, 1966: 161). The successful sublation ${ }^{6}$ of contradictions in social-life is only a possibility, something potential; human-beings can act to change the contradiction or opt for the status-quo and continue to exist, however unstably, within a state of contradiction. What dialectics suggests is that there will be movements to overcome such contradictions, not that these will amount to "a final inversion, happily emerging with affirmation in its hand" (Adorno, 1973: 161). The temptation to deploy dialectics as a predictive device reifies its concept and endows it with content that it cannot possess. Such approaches usually retreat to the static dialectical triad in order to 'pinpoint' the phenomena from which it is alleged that it is possible to predict any number of things. Aetiologically this is an impossibility however, for one cannot not know a priori which social factor/s will have causal effect, nor can one 'prove' that certain processes are historically necessary (see Freud 1933: 266-267).

Despite the potential benefits that could flow from the dynamic ontology of dialectics, mainstream IR theory has seldom discussed the dialectical method and, on the rare occasions that it has, its attention has usually focused on problematic structuralist forms of dialectics (Althusser, 1969 and Poulantzas, 1973). For many in the AngloAmerican IR tradition, the distorted account of dialectics provided by Popper who considered dialectics to be the philosophy of the enemies of the 'open society' has continued to hold sway. This has led to the dialectical method being popularly discredited, despite the fact that Popper's account was based on ideological grounds rather than the substance of dialectics itself, and despite the fact that Popper himself wielded a unique dialectical method in his own defence of what he called "anti- 
dogmatic" science (see 2002: 419-451, 1980, Vol. 2: 12ff) While there was the fanciful application of an idiosyncratic Hegelian dialectic in Fukuyama's 'end of history' thesis (1989: 3-18), there has been little substantive engagement with the concept of dialectics outside of the debates in Millennium in the early 1990s. ${ }^{7}$ With the rapid (and largely unpredicted) demise of the Soviet Union, most IR theorists have recognized that the discipline has clearly failed to grasp the dimension of large-scale social change - despite Fukuyama's insistence that we no longer need to. The study of processes of change has been at the forefront of recent IR scholarship (see Linklater, 2008: 160ff, Kurki, 2008, Buzan and Little, 2000, Hobden and Hobson, 2002) and it is contended here that dialectics, if integrated methodologically, could help the discipline to understand the root causes and possibilities of social change in world politics.

This is not to suggest that dialectics has been totally absent in IR theory. It has been shown that just under 10\% of IR scholars have employed a dialectical approach, at least up until the 1980s (Alker and Biersteker, 1984: 255). Moreover, some critical IR scholars including Richard Ashley (1984 (1986): 225, 286), Andrew Linklater (1990, 1992, 2008) and Robert Cox $(1983,1987,2002)$ have, and continue to use, dialectics in their methodological approaches. In a work that prefigured the argument here, Ashley, argued against the Althusserian Marxism that watered down dialectics, objectified human agency and produced a "mechanistic theory". To replace it, Ashley contended for a "dialectical competence model" (Ashley, 1986: 256, 294) which looked to the "possibility conditions" of existing structures/regimes and to crisis which may make transformation possible (Ashley, 1986: 296). In a different vein, Alker and Biersteker discussed the epistemological themes of dialectics and were concerned with problematising the discipline of IR, how it is taught, its dominant approaches, and in illustrating the dearth of dialectical accounts in IR literature (1984: 243). They did not aim to articulate the principles or provide the groundwork for a dialectical method of IR as is the purpose here, but argued for "genuine cross-paradigmatic fertilization" that integrated dialectical analysis. Alker's later work on emancipatory humanism (Alker, 1993: 347-371) and the study of possible futures (Alker et al, 2001) continued to pursue dialectical themes (see Patomäki, 2002, 2008). ${ }^{8}$ Like Ashley, Alker sought to replace positivism's preoccupation with prediction with critical reflectivism combined with an "orientation towards possible futures" in order "to historically enrich our sense of trajectory-changing possibilities." Here, as in the present article, dialectics was said to offer key insights into the study of social processes with a method that acknowledged the ambiguous nature of its undertaking but which nevertheless remained forward-looking and open-ended (Patomäki, 2008: 79, and Alker, 1988: 818).

Over a decade later, Heine and Teschke took up Alker and Biersteker's call and attempted to formulate a "dialectic of concrete totality" (1996: 404). ${ }^{9}$ Like Alker and Biersteker, they argued for inter-paradigm communication in IR and for a 'second-order', reflexive discourse involving both empirical and immanent modes of critique that was promised by the dialectical method (1996: 404-405). For them, dialectics was the most appropriate mode of understanding social development and differentiation in the dynamic context of global processes (1996: 411; Krombach, 1992: 250). They justified this claim on three "irrefragable premises" of dialectics: its comprehension of reality as 
contradiction, its concern with praxis as multiple sites of human action, and its notion of reason as the unfolding of human praxis with no fixed terminus (1996: 411-413). For Heine and Teschke, while subjects are constrained by their objectified externalizations (structures) the ontology of dialectics (its assumption of flux, of humankind as "becoming"), reveals that humanity's forms of engagement are "infinite", thus leading to open-ended patterns of social change (1996: 416). The importance of their approach lay in the acknowledgement of the fundamental importance of human relations in the dialectical process of change - and it is this notion of humankind's 'becoming' through forms of engagement that is referred to in this paper as intersubjectivity or socialrelations.

Heine and Teschke's thesis prefigured what is being argued here regarding the radical extension of accounts of intersubjectivity in world politics (1996: 421), in which the subject of analysis is not an abstract, isolated individual or sum-total of individuals, but is "a definite individual in his real relation to other individual and groups..." (1996: Note 66, citing Horkheimer, 1972: 210-212). Yet, despite the importance attached to intersubjectivity, Heine and Teschke did not expand upon this crucial aspect of their argument, instead proffering a dialectical account that focused on the centrality of labour and praxis rather than emphasising the importance of social-relations (1996: 417-419). As such, it is not so much what Heine and Teschke claim - which I hold to offer fundamental insights in establishing the groundwork for a dialectics of world politics but in what they leave under-stated that is the issue, in particular, the social-relational (intersubjectivist) basis of dialectics in world politics. For example, in The Myth of 1648 Teschke extended upon the Millennium debates and re-affirmed dialectics as both the appropriate meta-theory for IR and meta-narrative of world history (2003: 12). He argued that while there can be no general explanatory theory of history, this does not warrant an abdication to contingency or a retreat to thick narratives - history is not teleological but remains retrospectively intelligible, governed by the possible resolution/s of social conflicts (2003: 7, 273). Here, geopolitical pressures should not be reified to the 'international' sphere but should be linked to social property regimes that generate antagonisms between actors in world politics (2003: 13-32 and 2002: 7-8, 13, 25, 36). As such, Teschke clearly acknowledges the importance of social-relations within dialectical approaches but again, like in the Millennium debate, he does not make this the focus of his discussion. The difference between Teschke and myself therefore is that he places emphasises on the social-relations of property, while I seek to emphasise 'socialrelations' at a more general level. These are not mutually exclusive approaches however, they are methodologically inseparable parts of the same dialectical analysis of world politics.

\section{Outcomes from the Millennium Debates}

Before I go on to discuss the details of social-relational dialectics, it is necessary to discuss what emerged from the debates in Millennium. One criticism raised was the familiar Popperian charge that the 'open dialectic of concrete totality' advocated by Heine and Teschke - and by implication any form of dialectics - operated as a monistic theory, an alleged panacea for all questions (Albert and Lapid, 1997: 413). Such 
criticisms however, overlooked the considerable emphasis Heine and Teschke placed on Marx's description of the world as the ever-changing "ensemble of social relations" that worked against the possibility of any totalising or static conception of IR that claimed "transhistorical validity". Heine and Teschke railed against the possibility of rendering universal social laws or "once-and-for-all" definitions via the dialectical method (1996: 413-414). Moreover, their use of the word 'totality' did not refer to the aggregation of facts and was far removed from the postmodernist implication of a 'totalising' discourse. What Heine and Teschke meant by the 'dialectic of concrete totality' was the epistemological possibility of the cognisability of the parts in relation to the social totality (1996: 416), which bears no resemblance to the domination inherent to Hegel's second movement in the Logic (see Adorno, 1973: xix-xx, 1-14). This is consistent with the history of the concept of dialectics which has always supported plurality of viewpoints, whether in Plato's Dialogues (see Sophist, 1937: 221ff) or the examination of the complex social antagonisms in contemporary Critical International Relations Theory (Cox, 1981 (1986), 1983). The dialectical method does not claim to be a "magic master key" for all questions, the aporia to 'truth', but makes radical methodological pluralism central (Trotsky, 1971: 52, 76). The exclusion of rival approaches would in itself be undialectical for dialectics is an orientation towards contextual analysis consistent with, rather than opposed to, other approaches (Sciabarra, 2002: 393). While the ontology of dialectics assumes a causal link between social contradiction and social change, it does not claim to be the only method to understand this movement; other economic, political, cultural, and historical approaches must play considerable roles within dialectical analysis.

Another misapprehension of dialectics that arose from the Millennium debate was the claim made by Lapid and Albert that dialectics offered merely a "processual" view of the contradiction in social life and our "faulty" comprehension of them (1997: 406). 'Process philosophy', however, largely removes real subjects from analysis and replaces them with systemic factors/processes and is therefore essentially a return to mechanistic determinism rather than a dynamic examination of process. Such a view leads to a peculiar form of determinism, one which suggests rationality alone removes contradiction. This is why Schatzki's emphasis on understanding and intelligibility as the ordering medium in social existence in IR captures only half of the issue for it leaves out the central principle of dialectics; contradiction (1996: 13). To paraphrase Marx, it is the intersubjectivist contestation between existing and alternate ways of being that are shared and challenged between real, living beings that is the essence of dialectics. It is not a process of mere logical thought (Marx, 1962: Volume II, 403). While understanding and intelligibility may be central in the Wittgensteinian approach to social life, this does not mean shared understandings are non-contradictory merely because they are intelligible, nor that contradictions shall be overcome merely because they are understood.

This point becomes readily apparent if one makes a clear distinction between the dialectics of real opposition (i.e. oppositions in the social world) and logical contradiction (i.e. contradictions in the realm of ideas/thought) (Colletti, 1975; Setterfield, 1996). In logic, dialectics connotes a dialogue seeking truth and the exploration of logical contradictions in thought (i.e. Aristotle's Rhetoric and Topics) (see 
Arnhart, 1981: Chapter 2). Through dialogue, participants hope that disagreement will lead to greater approximations of 'truth' (Cox, 2001: 124). Yet dialectics does not apply just to conceptual development but also to real social relationships (Marković, 1965: 79). At the level of history, dialectics allows for the exploration of alternate forms of development that arise through the contradictions between opposed social forces (Cox, 1981 (1986): 133-134). Society contains real dialectical oppositions, that is, relations of 'contrariety' between real, living beings. This stands in contradistinction to both Kant's idealist (1988: 54) and Hegel's objective-idealist (1969b: 584) forms of dialectics which were primarily concerned with logical contradiction and conceptual adequacy. ${ }^{10}$ Hegel's objective-idealist dialectics was thoroughly criticised by Marx's because Hegel had mistakenly asserted that the logical route from the abstract-simple to the concretecomplex in the process of thought was the actual process in reality (Hegel, 1967, 283ff; Marx, 1973: 101-102). Marx thus sought to stand Hegel on "his head", substituting the real material world for the idea (1971: Volume I, 29). This was a view echoed by Lenin who posited that the fundamental misfortune of the metaphysical materialism of Hegel was its inability to apply dialectics from the theory of reflection (Bildertheorie) to the process and development of knowledge (1961: Volume 38, 362). The overcoming of contradiction in this latter form (i.e. in logic) is only one aspect of dialectics and its method is not necessarily applicable to the study of world politics based as it is in real, human relations.

As real oppositions are in fact mutual antagonisms between social beings (and/or groups), sublation can take place in any number of ways. There can be no fixed formula to describe the complexity and contingency of this process, nor can there be any certainty of prediction let alone a teleology of progression. What there can be however, is an understanding of this process through the study of the dialectical trajectories immanent to social tensions and the 'possible futures' contained therein (Alker et al, 2001; Patomäki, 2008). Unfortunately, some in IR like Krombach and Kratochwil have failed to adequately grasp this rather elementary distinction between "conceptual contradictions" and "real oppositions" (Krombach 1997: 425ff), writing as if idealist (logical) dialectics were the only form of dialectics - "Logic 101" as Kratochwil derides it (1997: 439-441). Yet an action/reaction, effect/counter-effect in a real social situation is not the same thing as the relation between logical categories of thought (Hegel's account of being and nothingness in the Logic for example). As stated by Ajdukiewicz, "If the action or the effect is a force, then the reaction or counter-effect is also a force - it is not simply the non-being of that force" (1958: 79-80). As contradictions in the dialectic of socialrelations are not logical but relational contradictions, when studying world politics we must move decidedly away from idealist dialectics towards a dialectic of real oppositions ('relations of contrariety').

If one adopted solely Hegel's dialectical typology and confounded logical contradiction as synonymous with real contrariety, as does Kratochwil (1997: 439-441), then 'synthesis' would be held to inevitably follow our perception, recognition or understanding of social contradiction. ${ }^{11}$ However, progressive sublation is not inevitable within real oppositions because social life does not just rely on logical. This is why we find so many unreconciled contradictions in social life and widespread acquiescence to 
these conditions. In social life, consciousness of contradiction is indeed a crucial step in the dialectical process of change, but without human agency it remains just that; the mere cognition of contradiction, not its sublation. As argued by Rosenthal, "nobody can ever be 'forced' to solve a problem" - indeed, "civilizations have been wrecked by problems that they have not faced..." (1971: 210) We can see even through the most superficial survey of contemporary human existence that we are capable of living with, even partially reconciling ourselves to, an incredible array of irrational and antagonistic ways of life. Imminent environmental collapse is a primary example of today's acceptance of irrational ways of life; exploitation and marginalisation of our fellow human-beings, the MADness of the bomb are others. These seem to confirms Adorno's retort that "society is full of contradictions... rational and irrational in one" (Adorno, 1976: 106).

It is important to realise that some forms of social contradictions can obtain a temporary degree of stability through the tacit acceptance of the antagonism. But this should not lead us back to a re-formulation of Bukharin's notion of dialectical equilibrium in which contradictions are said to permanently stabilise and fuse (1925). Rather, in such circumstances it is not that real contradictions have ceased to be contradictions because they seem temporally stable, it is that they are either unrecognized as such, or are recognised but are not sublated. For example, in Marx's Capital, economic laws that appear natural are seen to be nothing other than the objectification of human social-relations which have become distorted in collective intersubjective understanding. Under such conditions and patterns of recognition, human-beings no longer 'mutually' recognize each other except as formal rights bearers and potential property owners, resulting in extreme forms of social alienation (see McLellan, 1995: 78ff). Marx could be forgiven therefore in assuming that the proletariat would calculate its advantage, whatever degree of alienation, and seek to purposively alter these exploitative socioeconomic conditions - and yet their self-emancipation has not been forthcoming (Veblen, 1961: 444). This was also the problem identified in Horkheimer's initial program for Critical Theory. For Horkheimer, the proletariat had already developed a sense of injustice of capitalist relations and it was rationally assumed that this sense of injustice merely had to be systematically articulated by a critical and reflexive theory (cited in Honneth, 2008: 68-69). Yet the recognition of the inherent tensions and crisis prone nature of the capitalist economic system does not, of itself, create the social forces necessary to change it. In the face of crisis, even imminent environmental collapse, human-beings may choose not to change; this is both our gift and our burden.

Ollman has questioned whether such 'distortions' and ongoing social contradictions are due, at least in part, to limitations inherent to humankind's sensuality and mental powers (Ollman, 1971; 234). Yet such an explanation seems unduly fatalistic, negating human potentiality in deference to unidentified limitations in our faculties. Instead, these idiosyncratic tendencies, often tragic and inexplicable though they are, reveal the limits of given social conditions and the possibilities conditioned within them. They are manifestations of our inability to yet grasp the complexities of our conditions, or what Frederick Jameson referred to as the "impossible totality of the world system". As explained by Honneth, while an understanding of injustice should have in and of itself the rational force to convince subjects to create a social praxis of cooperation, it has not 
yet moved humanity to change to greater sociality. Such irrationality explains - though does not forgive - the existence of social injustice and the absence of any widespread public reaction against it (Honneth, 2004: 345). Consequently, we must appreciate that in social life dialectics cannot be reduced to some mechanistic, inexorable force that drives all forward to a rational, progressive synthesis, or hold faith in the power of reason that with the mere recognition of contradiction humankind shall immediately bring forth purposive change.

Under this conception, what makes the critique of existing social conditions conclusive is not the empirical evidence itself, nor the appeal to ethicality that may accompany such a critique, but what the intersubjectively derived consent of the community - or most dominant section thereof - wish to qualify as being conclusive. Dialectical critique as such, does nothing if it does not capture the minds of the community. This was recognized in the distinction made by Heine and Teschke between objective dialectics (dynamics of the social totality as it unfolds through social antagonism) and subjective dialectics (which comprehends the objective dialectic of appearance and essence) (1997: 418). It is only when contradictions are perceived as being contradictory, incompatible, and antagonistic in their unreconciled form that the dialectical processes of change and potential sublation can begin to take place (McTaggart, 1922: Chapter I, 6). What this suggests is that the exposition of contradiction through dialectical critique is nothing without mutual recognition of the contradiction, an intersubjectively shared desire to overcome the problem, and joint social action to change it. As such, we may still accept della Volpe's optimistic appraisal that dialectical contradiction can be a rational instrument for understanding real opposition (1980) whilst recognising that the movement to sublation is never guaranteed. Dialectics brooks no certainty of movement. The mediation of contending forces in real opposition is a social question, involving a complex nexus of agency and structure, power and intersubjectivity - it is up to $u s$.

\section{Determinist v. Dialectical approaches to IR theory}

Having now recounted the broad themes of dialectics as debated in IR theory, I wish to highlight the distinction between determinist and dialectical approaches to world politics by contrasting neo-realism and Coxian Critical Theory (Leysens, 2008). ${ }^{12}$ While the problems of neo-realism's positivist approach to IR have been well documented (Ashley, 1984 (1986), Cox, 1981 (1986)), one of its limitations becomes particularly obvious through the dialectical prism, namely the ahistoricism of neo-realism's 'system reproduction thesis'. In neo-realism, the conditions of international anarchy are considered to be reproductive in the sense that uncertainty and fear - Herz's security dilemma - leads to ongoing tensions in the billiard-ball interactions between states which reinforces existing patterns of uncertainty and leads to the self-perpetuation of these systemic features. From a dialectical point of view, this not only divests human-beings of agency but it reifies particular, historical conditions as not only determinative of human possibility but as perpetual fetters, immutable obstacles, on the human condition. Neorealism proclaims to be thoroughly materialist and yet is completely ahistorical; it denies any potential for humankind's self-creation, being as we are determined automatons 
structured by the systemic features of international anarchy (Anderson, 2007: 2). Here, neo-realism is seen clearly to privileges structure over agency (Linklater, 1996: 284). Yet at the same time, it cannot explain the genesis of the 'system' without appealing to historical factors that existed before the system arose and, as this would be tantamount to looking for causal conditions outside the 'system' itself, reveals a fatal contradiction at the core of the neo-realist thesis. Attributing casual agency to human subjects would erode the ontological claim of systemic analysis itself, after all, systems must determine agency inexorably in order to qualify as being 'systemic'. Waltz does distinguish between unit-level and system-level phenomena/explanation, yet primacy for systemreproduction is deferred to the latter and divests any role of the former in it. That is, while Waltz recognises that units have a capacity to influence the international system, in the main, he finds causality to flow in the opposite direction (Linklater, 2008: 48). Unfortunately, neo-realism seems not to have progressed beyond the unreflective form of consciousness that assumes the social world to be fixed and unalterable (Linklater, 1982: 11). Its claim to adequately capture 'reality' is therefore dubious at best.

Such positivist approaches to the study of the social world as exemplified in Walzian neo-realism were criticized by Marx as the "abstract materialism of natural science", a form of materialism that "excludes history and its processes" (Marx, 1971: 352). This is why dialectical approaches are so confronting to positivist accounts because they reveal positivism's inherent distortions - ahistorical analysis and structural determinism - that are posed as objective accounts of 'reality'. From the viewpoint of dialectics, the notion of systemic self-reproduction is seen to mystify the real nature of world politics for one cannot ascribe a higher reality to an alleged system than what its parts provide, otherwise we would witness the hypostatization of the whole bereft of its particulars re-rendered as a monolithic structure. A key methodological benefit of dialectics is that it avoids such "artificial prioritisation"; the isolation of parts from their "social genesis" (as in empiricism), or emptying the whole of its components and then abstracting them as a 'system' (as in Waltz's 'Third Image' analysis) (Heine and Teschke, 1996: 417). The agency/structure nexus is not recursive within dialectics so that structure determines agency and agency merely re-enacts structure. As stated by Teschke, this $i s$ a world of our making, but this making is neither the aggregate of voluntary and intentional actions, nor the outcome of desubjectified mechanisms of structural emergence (2003: 273). This echoes two of Marx's most famous adages, "circumstances make men just as much as men make circumstances" (Marx, Engels: 1974: 57-59) and from the Eighteenth Brumaire, that while we do make our own history, we do so not under conditions of our own choosing but those transmitted from the past (1963b). Change cannot be comprehended by the monocausal, systemic explanations given by neo-realism - and putting one's head in the proverbial sand and claiming that in world politics nothing much happens is, quite simply, not a scholarly answer. As argued by Suganami, to suggest that something happens automatically or of necessity, is not to explain it. What is required to make such a mechanistic process intelligible is to reveal the mechanism/s involved (Suganami, 2008: 335).

From a dialectical position, the various problems associated with neo-realism arise because it treats social phenomena as neutral objects governed by alleged 
universally valid laws - laws that are stable, permanent and cognizant only by experimentation and observation (Marcuse, 1960: 326). The object of study is observed completely unmediated from the social totality in which it is situated, with the result that the approach is blind to the object's relation to other objects, its own possibilities of internal development, and its own history. In distinction, for a social theory that proceeds dialectically, no facet of social reality can be understood by the observer as final or complete in itself. For every stage of phenomenological development there is a corresponding historical stage (Dunayevska, 1989: 9). It is the ahistorical study of supposedly neutral objects, their abstraction from both their interrelations with the external world and their own internal potential for development, that leads the positivist method of neo-realism into error. The seeming intractability between dialectics and positivism is, in part, due to the fact that they have opposed conceptions of what constitutes 'concrete' and 'abstract' analysis. Within the dialectical framework, 'concrete' means that which is "many-sided, adequately related, complexly mediated" while that which is "abstract" is that which is "one-sided, inadequately related, relatively unmediated" (Kline, 1967: 431; Jay, 1996: 82). This turns the categories of the traditional scientific approach on its head and the positivist simply cannot conceive. For them, what is 'concrete' is that which has been abstracted from and unmediated by its complex connections with the whole. What dialectics helps the social scientist to appreciate is the mediation inherent to social interaction and development, whereby all phenomena are to be regarded as mediated (interrelated) through the social totality of which they form a part (Jay, 1996: 54). It is for this reason that the notion of intersubjectivity is of crucial importance in the dialectic of world politics because it is by analysing the points of mediation between individuals and groups that we can identify areas of potential contradiction and development.

Even Mearsheimer, who typifies structural realism, is cognisant of the sophistication of Critical Theory's account structure and agency that interact in a dialectical fashion, though he suggests its explanation of how change occurs is "incomplete" - a charge that I believe a social-relational dialectic can overcome (1995: 40, Note 143, 42). Within world politics, change can be located within the vast array of social-relations themselves, something that the open-ended nature of dialectical analysis is well-equipped to explore by taking mechanistic causes and agential reasons, backgrounds and chance coincidences, and combining them as appropriate (Suganami, 2008: 340). This is the point where dialectical analysis meets historical narrative but moves beyond the latter by situating change within the horizon of possibilities present within existing social-relations. Here structure is no longer immune from agency but neither is agency sheer volition. Possibility lies within the conditions given by humankind's history and its potential agency, a balance that the agency/structure duality cannot grasp. What is "at stake" in this agency/structure debate is the conservative passiveness fostered by structural determinism and the active potential in humanity, the possibility of emancipation (see Dessler, 1989: 472-473 and Suganami, 1999: 379). Neorealism fixates only on 'presentness' which, from a dialectical points of view, is of the least relative importance to social studies as any moment is just one passing aspect of its entire trajectory. To only grasp the synchronic dimension is to mistake 'presentness' for history; temporary moments are meaningless in isolation, they must be regarded as 
moments in process (Marx, 1967, 329-33). By fixating on specific temporal moments, their actual existence, their manifold relations, and their process of development is hidden from view, bracketed off from the 'proper' subject matter of theoretical analysis. Waltz's neo-realism has taken a snapshot of world politics set amidst the background of Cold War hostilities and has reified this moment as the recurring, systemic pattern of IR and, by this hypostatisation, has rendered itself utterly incapable of understanding change.

Yet despite this self-evident limitation, neo-realism has no intention of inquiring into the social complexities of change, something which requires an epistemology that affirms the relation of subject/object in historical process, rather than wilfully ignoring it (Cox, 1992b: 135). Neo-realism, like structuralist sociology, is suited to account for forces that maintain the system's equilibrium rather than identifying the contradiction that may lead to the system's transformation (Cox, 1981 (1986): 127). ${ }^{13}$ The problem is that such 'traditional theory' (Horkheimer, 1972), or what Cox would later describe as 'problem-solving' theory (Cox, 1981 (1986): 128-129), "makes it difficult even to think about an alternative order" (Cox, 2002: xix). Social life is alienated from us, something that happens over us, beyond all human control. Neo-realism thus instils an ontos that precludes active utopian imagination (Brincat, 2009: 584ff), leading to what Ashley has called "the impoverishment of political imagination" (1986 (1984): 296). In contradistinction, social-relational dialectics can help answer the question of change in world politics precisely because of its focus on the principles of interconnectivity and mediation within the social realm. Of analytic importance are the social-relations within world politics and what their immanent tendencies portend for future developments. By thinking in abstract the dialectician can descend to the most simple determinations and parts of social phenomena, and from there, can begin to ascend to the concretised, or whole, social phenomena (Heine and Teschke, 1996: 412). It was Hegel who first contrasted the dialectical method with such approaches that viewed the world in distinct notions of fixity, employed deductive procedures, and which stressed the independence of principles from others (i.e. physics) (Findlay, 1958: 60). Yet for Hegel, idealism and empiricism occur in relation and have to be taken together; neither idealism or empiricism when taken alone is the truth, "but only taken together and as qualifying each other" (Williams in Grier, 2007: 49). These "two moments are not to be separated" for it is one-sided to assert that there is "nothing in the subject matter that was not imported into it" (i.e. subjective idealism) just as it is one-sided to "suppose that the resulting determinations are merely extracted from it" (i.e. realism) (Williams, 2007: 50 quoting Hegel, 1969b: 788). The sublation of both idealism and realism within dialectics has fundamentally important benefits for how we approach IR for it combines them epistemologically, thus preventing the errors that result from their alleged duality and opposition as in neo-realism.

Systemic approaches are not derided by dialectics as useless abstractions with no analytic value. Rather, they are seen as being in need of augmentation by a higher level of analysis that looks to the social-relations that are constitutive of them. The "Illusion of the Epoch" in IR theory - to borrow Marx's famous dictum (Marx, Engels, 1974: 57) - is present by the name of the subject itself, International Relations. While our field is right to identify relations as the focus of its analysis, it abstracts from the real relations of 
people within global civil society in deference to states themselves. This results in the absurdity that IR "confines itself to high-sounding dramas of princes and states", whilst neglecting the "real relationships" themselves (Marx, Engels, 1974: 57). In distinction, dialectics builds onto the 'chain' of our understanding, increasing the multidimensionality of analysis so that more complex determinations are able to be observed in social-relations, and hence the movement towards a fuller analysis than those proceeding it (see Likitkijsomboon, 1992: 407). The positivist epistemology of neorealism that is fixated on systemic features alone cannot grasp the importance of sociality as a generative mechanism of change and is therefore inferior to the relational essentialism of the critical tradition (Alker, 1982: 83).

Without dialectics, the danger for IR theory is that it may devolve to a static form of methodological positivism, adopting allegedly 'neutral' attitudes to existing social relations, ultimately leading to a naturalist account of social change (Marcuse, 1960: 398ff). In juxtaposition to stasis and immutability, dialectics aims to understand things in all their movement, change and interconnection; the constant interplay of "particular and universal, 'moment' and totality" (Horkheimer cited in Jay, 1996: 54, 257). To borrow Sciabarra's expression, viewed dialectically world politics is not an "ineffable organism" but a "complex nexus of interrelated institutions and processes, of volitionally conscious and acting individuals and their dynamic relations" (2002: 383). A dialectical method is successful precisely because its analysis necessitates a process of reflective judgement on relationships and interconnectedness, not just the abstraction of particular elements or moments (Ollman, 1971: 62ff). It views history as an "active life-process", wherein humankind is collectively capable and responsible for social self-production and who are simultaneously the producers and product of open-ended processes of history made under historically specific circumstances (Rupert in Dunne et al, 2007: 149-153). Under this lens, social structures generate the possibility of certain actions but are not in themselves determinative and what dialectical analysis can help identify are the possibilities for progressive social change immanent within these specific social conditions.

The critical theory espoused by Robert W. Cox illustrates these key features of a dialectical analysis of world politics. Leysens and Neufeld have argued that so-called 'Coxian' Critical Theory is superior because of its inherent dialectical basis, its commitment to considering how a particular order came about, the analysis of social contradictions therein, and its reflection on the possibilities for transformation immanent within existing social forces (Leysens, 2008: 109, Neufeld, 1995: 58-60). Its juxtaposition to neo-realism could not be more pronounced, nor more self-evident. Whereas neo-realism sees conflict in the world-system as a "recurrent consequence of a continuing structure", Cox's dialectical approach sees in social contradiction the possible cause of structural change (1981 (1986): 134). That is, for Cox, historical phases are produced in processes of contradiction and he looks at the problem of world order taken as a reciprocally interrelated whole with an awareness of not reifying the world as a system (1992b: 139, 135; 1981 (1986): 128). In this way, the capacity of dialectics to acknowledge the "historical malleability of structures" serves to differentiate it from structuralism that posits fixed and immutable structures (1992a: 176). It is this methodological feature that lies at the center of the difference between 'problem-solving' and 'critical theory'; the former "assimilates particular situation to general rules", 
whereas the latter "seeks out the developmental potential within the particular" (1996 (1985): 53). Following Vico, Cox contends that the inter-state system should not be thought of as "unchanging" but as a "continuing creation of new forms" (1981: 132). Structures are not 'givens' but 'mades', they are "made by collective human action and are transformable by collective human action" (Cox, 1987: 395). So whereas for Mrs. Thatcher and company "there is no alternative" (Cox, 1995: 22), for Cox, change is an ever-present possibility and "can occur at all levels" (1987: 8). For this reason, Cox makes central the distinction between the 'realism' of Morgenthau and Waltz, which adopted a fixed historical view, and that of Carr who saw history as conditioned but as susceptible to change - a view that Cox favoured (1981 (1986): 131).

Cox highlights five premises contained in a critical dialectical approach; an awareness that theory and action are never 'free'; an awareness of the relativity of each theory; an intention toward understanding change over time; a framework that analyses thought patterns, material conditions and institutions that constitute the "context" in which action takes place, and; a framework that looks from inside conflicts/contradictions for the possibilities of social transformation (1981 (1986): 135). Such a method can help us understand and act upon particular historical conjunctures through an ontology that focuses attention on the key elements of social struggle in world politics (Cox, 2002: 78, 94). It looks at structures within their historical context as "an interconnected series of historical hypotheses", namely, the interrelations between material capabilities, ideas and institutions, their origins, growth and potential demise of this array of social forces (1981 (1986): 139, 141). The point is to focus on the material condition that circumscribe - but do not determine - the potential for human activity, including production, states, world order, ideas, and institutions. This involves an awareness of the point at which material conditions act upon human consciousness (1995: 17-18) but avoids making one factor the explanatory 'originary ground' of all by basing analysis on the "reciprocal relationships" among the basic forces shaping social, ethical, ideological and political practice (Cox, 1996 (1985): 55, 1983: 168).

In this way, dialectics raises the possibility of analysing what Cox calls "counterstructures" immanent within existing world order (1981 (1986): 144). Cox describes these as "tendencies" only, potentialities in the "dialectic of opportunities" (1987: 258, 389) for he is no believer in historical inevitability (1996 (1992): 533). He endorses Marx's dictum in the Eighteenth Brumaire as a necessary step in understanding those conditions 'transmitted from the past' in which action is possible (1981 (1986): 241). Here, the subjectivity of "historical action" is situated within "an objectified historical process" (Cox, 1981 (1986): 248). This, for him, represents the interface between creative collective energy and the objective limits of the possible (1995: 24). From this perspective it is imprudent to offer predictions regarding the future of world order but there does remain a certain 'utility' in dialectical analysis that lays in its ability to draw attention to factors which "could incline an emerging world order in one direction or another" (1981 (1986): 149). Dialectics does not imply a 'sit-back and watch' or 'we can do nothing' attitude because through it we can "construct a partial knowledge" that may be helpful "in channelling the direction of events towards a desired option" (1992b: 139). The question for the dialectician then is to explore the forms these may take and in 
channelling them towards emancipatory ends rather than presenting some Platonic ideal or blue-print utopia that is to be put in effect (1991: 169). In social struggles, the precise outcome is never altogether predictable (1991: 170) but nevertheless there are alternatives - alternatives that are conceivable as the problems of our moral and social choices (2001: 123). Even so, intentionality alone is insufficient; intentions do not change history or social structures which require struggle and agency grounded in socialrelations. In dialectics, the telos of metaphysical inevitability is jettisoned but not one of purposive struggle.

While dialectics holds that the notions of flux or becoming to be the most expressive of actual being in the world, the fact that historical change can only be anticipated does not mean that dialectics is itself indeterminate, or that the complex web of social variables is retrospectively unknowable (Teschke, 2003: 7 and 273). At the same time however, just because dialectics affirms the ongoing process of change does not mean that it offers a 'progressivist' interpretation of IR, some automatic ascent towards global emancipation (Linklater, 2008: 37). There is a necessary contingency or openness inherent to the process of change and how the 'conditioning' factors operate in dialectics is not in the same manner in which they are conceived of in strict determinist or structuralist accounts (see Brincat, 2009 (forthcoming)). These operate far more contingently and their mutual influence is far from being determinative. Instead, these factors are involved in a process of "unanticipated development" leading ultimately to further change at an unspecified, conditional future time (Ball, 1979: 791). What comes out at the end of a given historical process cannot be known in advance as it is an outcome of a concatenation of a wide range of happenings, some of which are what people think and act, some of which are a matter of contingency, and some of which are a result of the conditioning factors in operation. ${ }^{14}$ It is because of this dynamic complexity that Horkheimer appropriately described the dialectic as being "unconcluded" (unabgeschlossene Dialektik) (Horkheimer quoted in Held, 1995: 182), or what I have termed elsewhere as being open-ended (Brincat, 2009).

What this amounts to is a clear rejection of mechanistic teleology, inevitabilist narratives, notions of endless progression or determined regression, end-stages of development, theories of stasis/immutability, and all manner of predictions and prognostications. At the same time however, dialectics remains committed to a weak telos, a telos without determinacy. Here human agency and a possibilist narrative replace the closed structures of the inevitability thesis. Merely because human actions are intentional and goal-oriented, does not imply inevitability or teleology. We may desire and work towards certain ends but it is not prefigured as a guaranteed outcome. Max Weber's observation that all social action is teleological in the sense of being goaloriented may appear truistic and trivial but for a dialectics that is firmly grounded in social-relations the implications are far-reaching. What dialectics offers is a reformulation and a regrounding of teleology as purposive human creation, a property of human subjectivity and agency that leaves development as something possible and openended, rather than inevitable or fixed ${ }^{15}$ Dialectics suggests that change in the social realm is reliant on human-beings themselves to make it - and another reference to the Brumaire would be here superfluous. 
This open-endedness in dialectics overcomes the propensity of IR scholars - like Krombach - to insist on characterizing the dialectical method as mechanistically teleological, as holding to "a self-consciously posited goal that awaits actualization" (1997: 421). There is simply no possibility for a teleological account of world politics that maintains an 'inevitability thesis' when the metaphysical mystifications of dialectics are removed and replaced instead with an emphasis on social-relations and human action. That is, there can be no teleology within a properly conceived dialectical approach, for teleology assumes some force working above the actors themselves. Even in Hegel's objective-idealist dialectics there is no telos given to the dialectic which remains, at all times, a process of change, not the change itself. The present is "pregnant with the future" (1970: 259) but this does not mean it is determined or inevitable. Dialectics is therefore concerned with causal analysis, a clear example being Patomäki's notion of a causal complex that enables a dialectical view on causality (2002). What dialectics offers is a fuller account of causal links and their interrelation through its method of abstraction and re-integration. As suggested by Suganami, accounts of 'causality' are by necessity nonempirical but theoretical, which means that there is no clear-cut, one-to-one, deterministic relationship between what is the cause and its effect. ${ }^{16}$ It is about possibilities of actualisation and the conditions of emergence, not prediction. Alker referred to this as "historical conditioning" (1981 (1986): 69) in order to emphasise the possibilist narrative that is precluded in determinist, structuralist and systemic accounts.

Ultimately, the ontological assumption of a social-relational dialectic is that sublation is altogether contingent on human praxis. This combines a focus on intersubjectivity (social-relations) within open-ended processes of social change. It rejects the teleological, inevitabilist account of progress, but retains the dialectical emphasis on the notion of flux by focusing on intersubjectivity as being generative of movement/change in social life. This alters the emphasis of dialectics from one of automatic progressiveness, to one that emphasises the notion of perpetual unrest without any assumption of how such unrest (contradiction) is going to be mediated in social life. So, while for Hegel the spirit of humankind "is never at rest, but carried along the stream of progress ever onward", my dialectical view holds that it is the notion of "perpetual unrest' rather than the assumption of 'progress', that we should hold onto as part of the dialectical ontology (Hegel, 1964: 75). This leaves as perpetually open the possibility of emancipation and makes central the fundamental role of human agency in the process of change, resistance and struggle towards it. Consequently, we must be mindful to guard against making a fetish of dialectics as if it were something outside and beyond human action $^{17}$ - alienating the process of change away from ourselves and our capacities. Instead, the dialectical method should be viewed as "a way of thinking" that brings into focus the full range of changes and interactions that occur in the world (see Ollman, 2003). Change does not come out of the ether, and by taking social-relations as central in this process, dialectics can tighten our analysis of transformation in world politics.

So what is the question that social-relational dialectics is the answer to?

What the proceeding discussion has intimated is that it is the question of change within the totality of world politics that a social-relational dialectic offers crucial insights. 
As suggested at the beginning of this paper, the unique contribution of social-relational dialectics is that it offers an alternate social ontology, one which centers on socialrelations as being generative of change, thus allowing IR to explore more adequately the dynamic processes at work within world politics. As many now openly acknowledge, "ontology lies as the beginning of any enquiry" (Cox quoted in Wight, 2006: 3) and contemporary IR theory must be addressed at the level of basic ontological assumptions because of the fundamental role these foundational assumptions have for the development and claims of theory (Walker quoted in Wight, 2006: 3). Yet, ontology is a veritable battlefield in IR theory because different theories have opposing views about the categorical structures, referent objects, and entities actually existing in 'reality' (Booth, $2007,184-185) .{ }^{18}$ The social ontology of social-relational dialectics is advocated here because it focuses on intersubjectivity, is reflexive, and retains a possibilist narrative that is without a strong telos.

The question to which a social-relational dialectics refers could therefore be reformulated as to 'what is the appropriate social ontology for explaining change in world politics?' If we start with intersubjective relations, that is, if we take the self/other distinction as being formative through social-relations rather than positing the self/other (external) relation as being foundational, then relations of intersubjectivity are revealed to be co-constitutive of the self and the other and not something that is only generated from them. ${ }^{19}$ For if the "I", the self, were all that existed, it would have no referent for "Other" and therefore have no conception of itself as an "I". It is only in social-relations, that is, relations with 'others' that the 'self' is constituted (as is the 'other'). Intersubjectivity therefore lies at the heart of the matter and is the formative essence of the self with the other. Hegel's double dialectic reveals how this relation is truly mutual, in that each is equally the originary ground of the other. ${ }^{20}$ In this view, 'being' is thoroughly intersubjective and a social-relational dialectic can reframe the social ontology of IR by focusing on social-relations without buying into a priori conceptions of self and other. This social-relational dialectic is not unique as Bottomore, Ollman and others have previously shown how Marx's dialectics committed him to a specific ontological relational dialectic (Bottomore et al, 1985: 125, Ollman, 1971: 233). As explained by Ollman, in the ontology of dialectics the "basic unit of reality is not a thing but a Relation" involving three key features; (1) viewing things as moments in their own development in, with, and through other things; (2) that 'relations' form the basic scaffold for dialectical development, and; (3) that to study problems we must look for relations between different entities and between past, present and future (1971: 233, 71, 52). The task of the social-relational dialectician is to reconstruct these intricate relations - most of which are not directly observable - between phenomena, institutions and persons (1971: 65). However, this methodological pre-commitment means that each subject is dealt with from a variety of different perspectives or vantage points. The result is that dialectical studies often appear repetitious because its subject matter involves intimate relations viewed methodologically from multifaceted and interrelated perspectives. It is easy to see therefore why Gramsci lamented that the dialectical approach is "something arduous and difficult" (quoted in Ollman, 1971: 433-436) but which, for the very same reason, holds great potential for the analysis of social-life. 


\section{Concluding remarks}

As posited by Cox, when choosing between approaches "much depends upon one's idea of what theory is for" (1981 (1986): 244) and as this article forms part of a larger research project concerned with emancipatory change in world politics, it is has sought to provide the groundwork of a method to help understand the complex phenomena of social movement within a possibilist narrative of freedom. This paper has provided an outline of an open-ended, social-relational account of a dialectical method suitable for IR theory that does not rest on prescriptive, exhaustive and pre-given modes of social mediation (Williams, 2001: 564). It points to causal potentialities for historical change embedded in social inequalities in world politics and therefore provides reasons for an historical account of emancipation, i.e., a history with political implications. It asserts that that history is potentially progressive and that an overcoming of social contradictions through human actions is an ever-present possibility. However, my rendering of social-relational dialectics in this article suggests only the groundwork of such an investigative procedure; the study of dominant social conditions and practices in IR, the examination of the immanent principles of development situated within intersubjectivity, and the possible fulfilment of the ideals and potentials for mutual recognition already pregnant in this world. Critical theorists of all persuasions, postmodernists in particular, should be interested in this conception of dialectics, shorn as it is of Hegel's problematic philosophy of history, because it can accommodate much of the postmodern concerns regarding plurality, difference and open-ended possibilities. Similarly, as the dialectical method here invites reflexivity whilst pursing emancipatory goals, it therefore guards against the danger of domination inherent to other efforts at emancipation (see Fay, 1977: 209). What is now required is an example of this form of dialectical analysis that can illuminate how intersubjective engagements are immanent to processes of change in world politics. I here contend that processes of recognition between human-beings in world politics and the recognition theoretic of Hegel and Honneth are suitable to explore both of these requirements (Hegel, 1977: § 178-196; Honneth, 1995). This future research will offer the next stage in social-relational dialectical analysis and employ this method toward understanding the transformative potential of recognition in world politics. 


\section{References}

Adorno, Theodor W., Negative Dialectics, (E. Ashton Trans.), New York: Continuum, 1973.

Adorno, Theodor W. Dahrendorf, R. Habermas, J. Pilot, H. Popper, K.R. (Eds) The Positivism Dispute in German Sociology, (G. Adey, D. Frisby Trans.), London: Heinemann, 1976.

Ajdukiewicz, K. Abriss der Logik, Berlin, 1958.

Albert, Mathias. Lapid, Yosef. "On Dialectic and IR Theory: Hazards of a Proposed Marriage", Millennium: Journal of International Studies, 26(2), 1997.

Alker, Hayward R. "Dialectical Foundations of Global Disparities", International Studies Quarterly, 25(1), 1981.

Alker, Hayward R. (Ed.). Dialectical Logics for the Political Sciences, Amsterdam: Rodopi, 1982.

Alker, Hayward R. Rediscoveries and Reformulations: Humanistic Methodologies for International Studies, Cambridge: Cambridge University Press, 1996.

Alker, Hayward R. "The Dialectical Logic of Thucydides' Melian Dialogue", The American Political Science Review, 82(3), 1988.

Alker, Hayward R. "The Humanistic Movement in International Studies: Reflections on Machiavelli and Las Casas", International Studies Quarterly, 36(3), 1993.

Alker, Hayward. Biersteker, Thomas. "The Dialectics of World Order: Notes for a Future Archaeologist of International Savoir Faire (1984)”, International Studies Quarterly, 28(2), June 1984.

Alker, Hayward R. Gurr, Ted. R. Rupesinghe, Kumar (Eds.). Journeys Through Conflict: Narratives and Lessons, Lanham MD: Rowman \& Littlefield, 2001.

Althusser, Louis. For Marx, London: Allen lane, 1969.

Anderson, Kevin. "Dialectics Today", (lecture presented at Wuhan University, China, 29 October 2007), published by the Marxist-Humanist Committee, http://marxisthumanismtoday.org/print/node/25. Accessed on $28 / 9 / 2008$.

Arnhart, Larry. Aristotle's Political Reasoning, Dekalb: Northern Illinois University Press, 1981.

Ashley, Richard. "The Poverty of Neorealism”, International Organisation, 38(2), 1984. Republished in R.O. Keohane (Ed.), Neorealism and its Critics, New York: Columbia University Press, 1986.

Ball, Richard A. "The Dialectical Methods: Its Application to Social Theory", Social Forces, 57(3), March 1979.

Booth. Ken. Theory of World Security, Cambridge: Cambridge University Press, 2007.

Bottomore, T. Harris, L. Kiernan, V.G. Miliband, R. Eds. A Dictionary of Marxist Thought, Oxford: Blackwell, 1985.

Brincat, Shannon. "Negativity and Open-Endedness in the Dialectic of World Politics", Alternatives: Global, Local, Political, 34(4), 2009a.

Brincat, Shannon. "Reclaiming the Utopian Imaginary in IR Theory", Review of International Studies, 35(3), 2009b. 
Brincat, Shannon. "Towards a Dialectic for World Politics" (paper presented at the Oceanic Conference on International Studies, Brisbane, 2-4 July 2008).

Bukharin, N.I. Historical Materialism: A System of Sociology, New York: International Publishers, 1925.

Barry Buzan, Richard Little. International Systems in World History: Remaking the Study of International Relations, Oxford: Oxford University Press, 2000.

Chandler, David. "The Limits of Post-Territorial Political Community: From the Cosmopolitan Politics of Global Civil Society to the Biopolitics of the Multitude" in The Future of Political Community, (D. Chandler, J.Bartelson Eds.), London: Routledge, 2009.

Colletti, Lucio. "Marxism and the Dialectic", New left Review, I/93, Sept-Oct 1975.

Cox, Robert W. Approaches to World Order, Cambridge: Cambridge University Press, 1996.

Cox, Robert W. "Civilisations and the twenty-first century: some theoretical considerations", International Relations of the Asia-Pacific, 1, 2001.

Cox, Robert W. “Civilisations: Encounters and Transformations”, Studies in Political Economy, 47, 1995.

Cox, Robert W. “Gramsci, Hegemony and International Relations”, Millennium, 12(2), 1983.

Cox, Robert W. "Multilateralism and World Order”, Review of International Studies, 18, 1992a.

Cox, Robert W. Production, Power, and World Order: Social Forces in the Making of History, New York: Columbia Press, 1987.

Cox, Robert W. “'Real Socialism' in Historical Perspective”, The Socialist Register, 1991.

Cox, Robert W. 'Social forces, states and world orders: beyond international relations theory', Millennium, 10(2), 1981, 126-155. Reprinted in R.O’ Keohane (Ed.), Neorealism and its Critics, New York: Columbia University Press, 1986, 204-254.

Cox, Robert W. The Political Economy of a Plural World: Critical Reflection on Power, Morals and Civilisation, (with M.G. Schechter), New York: Routledge, 2002.

Cox, Robert W. "Towards a Post-Hegemonic Conceptualisation of World order: Reflections on the Relevancy of Ibn Khaldun", in J.N. Rosenau, E-.O Czempiel (Eds.), Governance without Government: Order and Change in World Politics, Cambridge: Cambridge University Press, $1992 \mathrm{~b}$.

Croce, Benedetto. What is Living and What is Dead of the Philosophy of Hegel, New York: Russell \& Russell, 1915.

Dessler, David. "What's at stake in the in the Agent-Structure Debate?", International Organisation, 43(3), 1989.

Dunayevska, Raya. Philosophy and Revolution: From Hegel to Sartre and From Marx to Mao, New York: Columbia University Press, 1989.

Dunne, T. Kurki, M. Smith, S. (Eds.), International Relations Theories: Discipline and Diversity, Oxford: Oxford University Press, 2007.

Fay, Brian. "How People Change Themselves", in Political Theory and Praxis, (T. Ball Ed.), Minneapolis: University of Minnesota Press, 1977. 
Findlay, J.N. Hegel: A Re-Examination, London: George Allen \& Unwin, 1958.

Freud, Sigmund. "The Psychogenesis of a Case of Homosexuality in a Woman", Collected Papers, II, London, 1933.

Fukuyama, Francis. "The End of History”, The National Interest, Summer 1989.

Grier, Philip T. (Ed.). Identity and Difference: Studies in Hegel's Logic, Philosophy of Spirit, and Politics, New York: State University of New York Press, 2007.

Hegel, G.W.F. Hegel's Philosophy of Nature, Part Two of the Encyclopaedia of the Philosophical Sciences, (A.V. Miller Trans.), Oxford: Oxford University Press, 1970.

Hegel, G.W.F. Phenomenology of Mind Part One of the Encyclopaedia of the Philosophical Sciences (abridged), n.d, at http://www.class.uidaho.edu/mickelsen/ToC/Hegel\%20\%20Philosophy\%20of\%20Mind.htm. Accessed on 6/10/2008.

Hegel, G.W.F. Phenomenology of Mind, (Trans. J.B. Baille), London: George Allen \& Unwin, 1964.

Hegel, G.W.F. Phenomenology of Spirit, (A.V. Miller Trans.), Oxford: Oxford University Press, 1977.

Hegel, G.W.F. Science of Logic, (A.V. Miller Trans.), London: Allen \& Unwin, 1969b.

Hegel, G.W.F. System der Sittlichkeit, G. Larson Ed.), Hamburg: Meiner, 1967.

Heine, Christian. Teschke, Benno. "On Dialectic and International Relations: A Reply to Our Critics", Millennium: Journal of International Studies, 26(2), 1997.

Heine, Christian. Teschke, Benno. "Sleeping Beauty and the Dialectical Awakening: On the Potential of Dialectic for International Relations”, Millennium: Journal of International Studies, 25(2), 1996.

Held, David. Introduction to Critical Theory: Horkheimer to Habermas, Cambridge: Polity Press, 1995.

Hobden, Steve. Hobson, John (Ed.). Historical Sociology of International Relations, Cambridge:

Cambridge University Press, 2002.

Honneth, Axel. “A social pathology of reason: on the intellectual legacy of Critical Theory”, in The Cambridge Companion to Critical Theory, Cambridge: Cambridge University Press, 2004.

Honneth, Axel. "The Social Dynamics of Disrespect: On the Location of Critical Theory Today", in Disrespect, (J. Ganahl Trans.), Cambridge: Polity Press, 2008.

Honneth, Axel. The Struggle for Recognition: The Moral Grammar of Social Conflicts, (J. Anderson Trans.), Cambridge, MA: The MIT Press, 1995.

Horkheimer, Max. "Traditional and Critical Theory", in Critical Theory: Selected Essays New York: Seabury Press, 1972.

Jackson, Patrick Thaddeus. "Hegel's House, or 'People are states too", Review of International Studies, Vol. 30(2), 2004.

Jay, Martin. The Dialectical Imagination, Berkley: University of California Press, 1996.

Kant, Immanuel. Logic, (R.S. Hartman, W. Schwarz Trans.), New York: Dover Publications, 1988. 
Kaufmann, Walter. Hegel: A Reinterpretation, New York: Anchor Books, 1966.

Kline, George. "Some Critical Comments on Marx's Philosophy”, in Marx and the Western World, (N.

Lobkowicz Ed.), Notre Dame, 1967.

Kratchowil, Friedrich. "Awakening or Somnambulation?”, Millennium: Journal of International Studies, 26(2), 1997.

Krombach, Hayo. "International Relations as an Academic Discipline", Millennium: Journal of International Studies, 21(2), 1992.

Krombach, Hayo. "Dialectic as the Philosophical Science of Socio-Historical Relations", Millennium: Journal of International Studies, 26(2), 1997.

Kurki, Milja. Causation in International Relations: Reclaiming Causal Analysis, Cambridge: Cambridge University Press, 2008.

Lenin I.V. Philosophical Notebooks, Collected Works, Moscow: Progress Publishers, 1961, Vol. 38.

Leysens, Anthony. The Critical Theory of Robert W. Cox: Fugitive or Guru? New York: Palgrave Macmillan, 2008.

Likitkijsomboon, Pichit. "The Hegelian Dialectic and Marx's Capital", Cambridge Journal of Economics, 16, 1992.

Linklater, Andrew. Beyond Realism and Marxism: Critical Theory and International Relations, London: Macmillan, 1990.

Linklater Andrew. Critical Theory and World Politics: Citizenship, sovereignty and humanity, Special Indian Edition, Delhi: Manohar, 2008.

Linklater, Andrew. Men and Citizens in the Theory of International Relations, London: MacMillan Press, 1992/1982.

Linklater, Andrew. "The Achievements of Critical Theory”, (S. Smith, K. Booth, M. Zalewski Eds.), International Theory: Positivism and Beyond, Cambridge: Cambridge University Press, 1996.

Marcuse, Herbert. Reason and Revolution, Boston: Beacon Press, 1960.

Marković, Mihailo. "Humanism and Dialectic", in E. Fromm Ed., Socialist Humanism: An International Symposium, New York: Doubleday \& Company Inc, 1965.

Marx, Karl. Capital, (S. Moore, E. Aveling Trans, F. Engels Ed.), Moscow: Progress Publishers, 1971, Volume I.

Marx, Karl. Grundrisse, Foundations of the Critique of Political Economy, Rough Draft 1857-1858, (M. Nicolaus Trans.), Harmondsworth: Penguin, 1973.

Marx, Karl. "Kritik der Hegelschen Dialektik und Philosophie überhaupt", in K. Marx, F. Engels, Werke: Ergänzungsband I, Berlin: Dietz Verlag, 1968.

Marx, Karl. "The Eighteenth Brumaire of Louis Bonaparte", in R.C. Tucker (Ed), The Marx-Engels Reader, New York: Norton, 1963 b.

Marx, Karl. Engels, Frederick. Karl Marx and Frederick Engels Selected Works, Fifth Impression, Moscow: Foreign Languages Publishing House, 1962, Vol. II. 
Marx, Karl. Engels, Frederick. The German Ideology, (C.J. Arthur Ed.), New York: International Publishers, 1974.

Marx, Karl. Engels, Frederick. Writings of the Young Marx on Philosophy and Society, (L.D. Easton, K.H Guddat Eds. And Trans.), New York: Garden City, 1967.

Mayo, Henry B. Introduction to Marxist Theory, New York: Oxford university Press, 1960.

McLellan, David. The Thought of Karl Marx, London: Macmillan, 1995.

McTaggart, John (McTaggart Ellis). Studies in the Hegelian Dialectic, Cambridge: Cambridge University Press, 1922.

Mearsheimer, John. “The False Promise of International Institutions”, International Security, 19(3), 1995.

Mueller, Gustav E. "The Hegel Legend of "Thesis-Antithesis-Synthesis", Journal of the History of Ideas, 19(3), June 1958.

Neufeld, Mark. The Restructuring of International Relations Theory, Cambridge: Cambridge University Press, 1995.

Ollman, Bertell. Dance of the Dialectic: Steps in Marx's Method, Chicago: University of Illinois Press, 2003.

Ollman, Bertell. Alienation: Marx's Conception of Man in Capitalist Society, Cambridge: Cambridge University Press, 1971.

Patomäki, Heikki. After International Relations, Critical Realism and the (Re)construction of World Politics, London: Routledge, 2002

Patomäki, Heikki. "Tributes to Hayward R. Alker: Learning from Alker: The Fifth Lesson”, International Political Sociology, 2(1), 2008.

Plato, The Dialogues of Plato, (B. Jowett Trans.), New York: Random House, 1937, Volume II.

Popper, Karl. The Open Society and its Enemies, Volumes 1 and 2, London: Routledge and Kegan Paul, 1980.

Popper, Karl. "What is Dialectic?" republished in Karl Popper, Conjectures and Refutations: The Growth of Scientific Knowledge, London: Routledge Classics, 2002.

Poulantzas, Nicos. Political Power and Social Class, London: New Left Books, 1973.

Rosenthal, Abigail L. "A Hegelian Key to Hegel's Method”, Journal of the History of Philosophy, Vol. 9, 1971.

Schatzki, Theodore R. Social Practices, Cambridge: Cambridge University Press, 1996.

Schneider, L. "Dialectics in Sociology", American Sociological Review, Vol. 36, August 1971.

Sciabarra, C.M. "Reply to Roderick Long: Dialectical Libertarianism: All benefits, no hazards", The Journal of Ayn Rand Studies, 3(2), Spring 2002.

Setterfield, M. ‘’Keynes’ Dialectics”, mimeo, Trinity College, Hartford, CT, 1996. 
Sugnami, Hidemi. “Agents, Structures, Narratives”, European Journal of International Relations, 5(3), 1999.

Suganami, Hidemi. "Narrative Explanation and International Relations: Back to Basics", Millennium: Journal of International Studies, 37(2), 2008.

Teschke, Benno . "Theorising the Westphalian System of States: International Relations from Absolutism to Capitalism", European Journal of International Relations, 8(1), 2002.

Teschke, Benno. The Myth of 1648, London: Verso, 2003.

Teschke, Benno. Heine, Christian. "The Dialectic of Globalisation: A Critique of Social Constructivism", in M. Rupert, H. Smith (Eds.), Historical Materialism and Globalisation, London: Routledge, 2002.

Thalheimer, A. Introduction to Dialectical Materialism - The Marxist World View, Covici Friede, 1927.

Trotsky, Leon. In Defence of Marxism, London: New Park Publications, 1971.

Veblen, Thorstein. "The Economics of Karl Marx: II", in The Place of Science in Modern Civilisation and Other Essays, New York, 1961.

Volpe, Galvano Della. Logic as a Positive Science, New York: Verso Books, 1980.

Wight, Colin. Agents, Structures, and International Relations: politics as ontology, Cambridge, Cambridge University Press, 2006.

Williams, Michael. "Mysticism, method and money in the Marx-Hegel dialectic", Cambridge Journal of Economics, Vol. 25, 2001.

\section{ENDNOTES}

1 BA (Hons), LLB (Hons), PhD Candidate, School of Political Science and International Studies, University of Queensland. I would like to thank Martin Weber for his invaluable supervision. I would also like to thank Hidemi Suganami, Andrew Linklater and Heikki Patomäki for their helpful comments. Part of this research was made possible by the award of a University of Queensland Graduate School Research Travel Grant. This is a heavily revised version of a paper presented at the Third Biennial Oceanic Conference on International Studies (OCIS). See Shannon Brincat, "Towards a Dialectic for World Politics" (Oceanic Conference on International Studies (OCIS), Brisbane, 2-4 July 2008), 1-26.

${ }^{2}$ I use this term not as a normative concept but as means to extend the scope of world politics to include the social-relations of global community typically overlooked in approaches to IR that focus on systemic analysis or the behaviour of states alone. It should be clearly distinguished from ideas relating to the specific concept of 'global civil society' (see David Chandler, 2009). I thank an anonymous reviewer for highlighting this problem.

${ }^{3}$ Plekhanov was probably the first to use the term 'dialectical materialism' in 1891. It was the first generation of Marxists after Marx's death that used "Diamat", a shorthand term that became current in the USSR (See Bottomore, et. al, 1985: 120-121).

${ }^{4} \mathrm{I}$ thank an anonymous reviewer for pointing this out.

${ }^{5}$ Though Thalmeimer (1927) has argued there have been only four stages of development, I would argue there has been six; (i) the dialectics of nature (Heraclitus); (ii) dialectics as a form of dialogue/persuasive argumentation (Plato/Socrates); (iii); transcendental dialectics (Kant); (iv) objective-idealist dialectics (Hegel); (v) historical and dialectical materialism (Marx), and; (vi) negative dialectics (Adorno). 
${ }^{6}$ Hegel's concept of Aufhebung, translated most adequately as 'sublation', is a term that means the dialectical movement that both surpasses and conserves (see Hegel, 1969b: 106-108, and Williams in Grier, 2007: 45).

${ }^{7}$ There were also two books published by Alker that made dialectic central to IR theory but which did not receive the attention they deserved (Alker (Ed.), 1982 and Alker, 1996).

${ }^{8}$ I thank Heikki Patomäki for drawing this to my attention (see Heikki Patomäki, 2002; 2008: 78).

${ }^{9}$ While the details of this formulation are beyond this paper to explore, Heine and Teschke's "dialectic of concrete totality" possessed four "dialectical dimensions"; the social or concrete totality, context of justification, historicity and praxis (1996: 404).

${ }^{10}$ Another term for this could be 'struggle between opposites' (Colletti, 1975) or struggle between 'real conflicting forces' (Setterfield, 1996).

${ }^{11}$ The distinction between social-relations of contrariety and contradictions in logic is that there can be no "subjective impotence of reason" in logic for it cannot remain in a state of contradiction. Once recognized, contradiction in logic must be sublated, it cannot remain (see Croce, 1915: "I: The Dialectic or Synthesis of Opposites").

${ }^{12}$ Cox's work is not the only form of dialectical analysis in IR but has been selected to highlight the methodological benefits of dialectics over traditional approaches.

${ }^{13}$ World-system's theory has also been derided by Cox for its lack of an ability to explain change and structural transformation (see Cox, 1992a: 176-177 Cox, 1987: 270).

${ }_{15}^{14}$ I thank Hidemi Suganami for pointing this out (see Suganami, 1999).

${ }^{15}$ I thank an anonymous reviewer for this discussion.

${ }^{16}$ Causality involves any number of counter-factuals which cannot be empirically proven. Causal processes are not always deterministic but contingent on context, i.e. causal potentialities manifest themselves only when the requisite conditions are met contingently; any outcome is an outcome of a complex set of conditions and similar outcomes are realisable in different ways. I thank Hidemi Suganami for this discussion (see Suganami, 1999 and 2008).

${ }^{17}$ Horkheimer warned against the danger of the "fetishisation of dialectics" (See Horkheimer quoted in Jay, 1996: 54, 79).

${ }^{18}$ I thank Charlie Thame for a discussion on this point.

${ }^{19}$ I thank Martin Weber for a discussion on this point.

${ }^{20}$ The concept of the double dialectic is too vast for the confines of this article. For details on the double dialectic see and Maker and Williams in Grier (2007) and Brincat (2009a). 